B.L. Weber. 2000. BRCA1 and BRCA2 mutations in breast cancer families with multiple primary cancers. Clin. Cancer Res. 6:4259-4264

13.White, M.B., M. Carvalho, D. Derse, S.J. O'Brien, and M. Dean. 1992. Detecting single base substitutions as heteroduplex polymorphisms. Genomics 12:301-306.

The work was supported by National Cancer Institute grant no. K01 CA76970 to M.A.V.-C. and no. P30 CA16058 to The Ohio State University Comprehensive Cancer Center. Address correspondence to Dr. Miguel A. Villalona-Calero, Arthur $G$. James Cancer Hospital, Ohio State University, B406 Starling-Loving Hall, 320 W10th Avenue, Columbus, OH 43210-1240, USA. e-mail:villalona-1@medctr.osu.edu

Received 19 October 2001; accepted 19 February 2002.

W. Duan, H. Ding, W.-G. Zhu, K. Srinivasan, G.A. Otterson, and M.A. Villalona-Calero The Ohio State University College of Medicine and Public Health Columbus, OH, USA

\section{cAMP Binding Protein Assay for Widespread Use in Cell Signaling Studies}

BioTechniques 33:66-72 (July 2002)

\section{ABSTRACT}

cAMP plays a critical role in intracellular signaling pathways that regulate proliferation or differentiation. The cAMP binding protein assay, using a naturally derived cAMP binding protein, is one of the most widely used methods for cAMP determination. The major steps of this binding assay include purification of the binding protein, cAMP extraction from samples, and quantification of the cAMP. Most purification methods of the cAMP binding protein were published before 1975, and many of the materials and methods are outdated. Here we describe an updated method of purification of cAMP binding protein from bovine skeletal muscle with the advantages of sim plicity, low cost, and high yield. The isolation procedures can be completed in two days using commercially available materials and equipment. The cAMP binding properties of the isolated protein can be utilized for more than two years. Binding protein isolated from $1 \mathrm{~kg}$ bovine muscle is sufficient for at least 3 $\times 10^{4}$ assay tubes. Furthermore, we describe the techniques of cAMP extraction and quantification that have been used successfully in studying parathyroid hormone signaling as an example of a $G$ protein-linked seven transmembrane domain receptor that signals through the protein kinase A pathway.

\section{INTRODUCTION}

cAMP was discovered and recognized as a second messenger in intracellular signaling pathways more than 40 years ago (15). Since that time, cAMP-dependent signaling has been under intense scrutiny in physiological systems such as the nervous $(10,16)$ and skeletal systems $(1,2)$, and in pathologic conditions such as carcinoma $(3,9)$. In the last year alone, more than 5000 cAMP-related publications were listed in Medline.

Many hormones exert their specific functions through binding to seven transmembrane domain G-protein coupled receptors. The cAMP pathway is downstream of receptors that couple to Gs, one of the heterotrimeric GTP-binding proteins. Activation of Gs releases Gs $\alpha$, which activates adenylate cyclase and subsequently leads to cAMP generation. The increase in cAMP activates cAMP-dependent protein kinase A (PKA), which subsequently phosphorylates specific substrates to generate cellular responses. Thus, the determination of cAMP levels plays a critical role in evaluating PKA-mediated signal transduction. The most widely employed techniques to quantify cAMP levels are based on the principle of competition binding, such as radioimmunoassay (RIA) $(4,5)$, enzymatic immunoassay (EIA) (8), and binding protein assay (13). In immunoassays, a cAMP-specific antibody is used for competitive binding between radiolabeled cAMP (RIA) or enzyme-conjugated cAMP (EIA) and the cAMP in samples or standards. In contrast, the binding protein assay involves the competitive binding between cAMP in samples or standards and $\left[{ }^{3} \mathrm{H}\right] \mathrm{cAMP}$ to a naturally derived cAMP binding protein. Disadvantages of RIA or EIA are that the antisera used for immunoassays are difficult to prepare. Further, although commercial immunoassay kits are available with high sensitivity, the unit price/sample is high; hence, it becomes quite expensive for repetitive or large-scale experiments. Finally, the shelf life of commercial assays that utilize iodinated cAMP is short and can limit the design of experiments to optimize the activity of the iodinated tracer. For routine determination of cAMP levels, the binding protein assay is likely a better choice. The binding protein used is easy to prepare with high yield and is stable for months to years. In addition, the binding protein assay possesses the advantages of simplicity, low cost, and high specificity. The binding protein assay has been successfully utilized for determination of cAMP levels in various tissue samples and cell cultures.

The major steps of the cAMP binding protein assay include purification of the binding protein, cAMP extraction from samples, and quantification of cAMP. The major obstacle of using a straightforward cAMP binding protein assay is the availability of cAMP binding protein. Most cAMP binding protein purification protocols were published more than 25 years ago $(7,14,17)$. They were either complicated or used outdated materials and equipment, which ren-

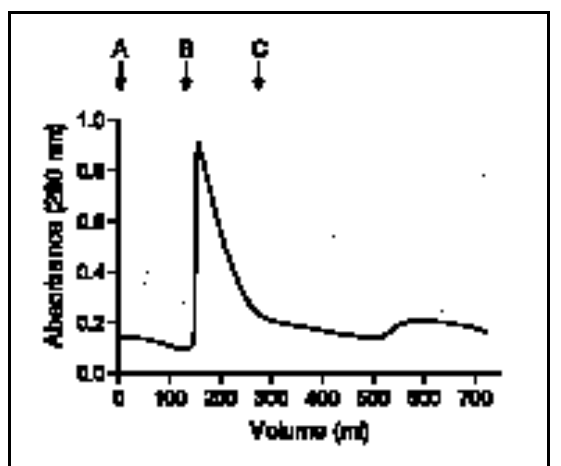

Figure 1. DEAE-cellulose chromatograph. Potassium phosphate buffer (as described in Materials and Methods) was added at time point A to elute the cAMP binding protein. cAMP binding protein was collected between time points $\mathrm{B}$ and C. Time points $B$ and $C$ were 1 and $2.2 \mathrm{~h}$ after time point A, respectively. Flow rate was $135 \mathrm{~mL} / \mathrm{h}$. 
dered the cAMP binding protein assay less and less common. With the increasing interest in cell signaling, there is a need for new techniques that are simple yet effective and sensitive for analyzing large numbers of samples without high cost. The protocol presented here adapts and extends a traditional technology for efficient use in the current landscape of functional proteomics.

\section{MATERIALS AND METHODS}

\section{Source}

Fresh bovine skeletal muscle was obtained from a local slaughterhouse and kept on ice during transportation. Blood and fat were removed before isolating the cAMP binding protein. The muscle was cut into small pieces and ground finely with a meat grinder. One kilogram of muscle was used to isolate purified cAMP binding protein.

\section{Extraction}

Three extractions were performed at $25^{\circ} \mathrm{C}$ as described previously (6). Briefly, for the first extraction, $1 \mathrm{~L}$ distilled water was added to the ground muscle; the mixture was then stirred for 5 min using a Kitchen-Aid ${ }^{\circledR}$ mixer and filtered through two thicknesses of cheesecloth into a container cooled in ice. A relatively small volume of filtrate is typically obtained from the first extraction. The muscle was reextracted with another liter of distilled water for $10 \mathrm{~min}$ and filtered through cheesecloth again. A third extraction was done with $500 \mathrm{~mL}$ distilled water. All extracts were combined and centrifuged at $15300 \times g$ for $30 \mathrm{~min}$ at $4^{\circ} \mathrm{C}$. The supernatant was filtered through fluted filter paper (Fisher Scientific, Pittsburgh, PA, USA) to remove traces of fat on the solution surface. The filtrate was then further purified by acid precipitation of contaminating proteins to isolate binding protein.

\section{Acid Precipitation of Contaminating Proteins}

The $\mathrm{pH}$ of the supernatant was adjusted to 5.9 by adding $50 \mathrm{mM} \mathrm{HCl}$ while stirring and kept at $4^{\circ} \mathrm{C}$ for $5-10$ min (6). The mixture was centrifuged at $15300 \times g$ for $20 \mathrm{~min}$ at $4^{\circ} \mathrm{C}$. Traces of suspended material on the surface were removed, and the supernatant was used in subsequent fractionation.

\section{Ammonium Sulfate Fractionation}

The ammonium sulfate fractionation was performed as described previously with slight modification (17). The supernatant was adjusted to $\mathrm{pH} 6.8$ with $1 \mathrm{M}$ potassium phosphate buffer, $\mathrm{pH} 7.2$ and then fractionated by adding $32.5 \mathrm{~g}$ am monium sulfate (Sigma, St. Louis, MO, USA) per $100 \mathrm{~mL}$ protein solution (added slowly and stirred for at least 30 min). The precipitate was collected by centrifugation at $15300 \times g$ for $20 \mathrm{~min}$ at $4^{\circ} \mathrm{C}$ and then dissolved in $130 \mathrm{~mL} 5 \mathrm{mM}$ potassium phosphate buffer, $\mathrm{pH}$ 7.0, containing $2 \mathrm{mM}$ EDTA. The protein solution was centrifuged at $15300 \times g$ for

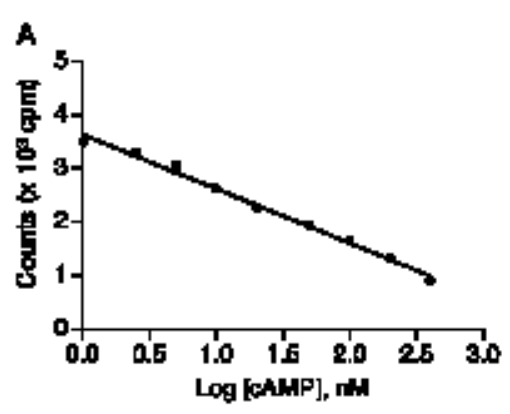

\begin{tabular}{|c|c|c|}
\hline \multirow{3}{*}{ [aris] } & \multirow{2}{*}{\multicolumn{2}{|c|}{ Gurt: [eim }} \\
\hline & & \\
\hline & Tube 1 & $T T^{\prime}, \mathrm{z}$ \\
\hline 1 & Axis & 344 \\
\hline LE & $20 t$ & ate \\
\hline $\mathbf{s}$ & $514+1$ & 205 \\
\hline 10 & 20F7 & 묘묘 \\
\hline 2 & 209 & Ert \\
\hline 50 & 19f-1 & Bn, \\
\hline 100 & 160 & $17 \mathrm{y}$ \\
\hline 200 & 1694 & 12.1. \\
\hline 400 & $\mathrm{TH}$ & $m a$ \\
\hline
\end{tabular}

Figure 2. Standard curve for cAMP binding protein assay. Duplicate cyclic AMP standards from 0.1 to $40 \mathrm{pmol}$ PTH in $100 \mu \mathrm{L}$ (equal to $1-400 \mathrm{nM}$ ) were used according to the cAMP binding protein assay procedures. (A) Under the saturating concentrations of $\left[{ }^{3} \mathrm{H}\right] \mathrm{cAMP}$, the standard curve is linear on counts versus logarithmic value of cAMP standards (in $n M$ ). The data are expressed as $\bar{x} \pm$ S E M (B) Counts versus cAMP concentration of the duplicate tubes of cAMP standards. 


\section{Short Technical Reports}

20 min at $4^{\circ} \mathrm{C}$. The resulting supernatant was desalted (to reduce the solution salt concentration to less than $0.1 \mathrm{M}$ ) by dialysis with Spectra/Pro ${ }^{\circledR} 1$ dialysis membrane (MWCO 6000-8000; Spectrum Laboratories, Rancho Dominguez, CA, USA) against 14 L buffer containing $5 \mathrm{mM}$ potassium phosphate buffer, pH 7.0, and 2 mM EDTA. The protein solution was then centrifuged as before, and the supernatant was collected.

\section{DEAE-Cellulose Chromatography}

DEAE-cellulose chromatography was performed by adsorbing the cAMP binding protein on a DEAE-cellulose (Sigma) column $(2.5 \times 30.5 \mathrm{~cm})$ equipped with a UA-5 absorbance/fluorescence detector with type 6 optical unit (ISCO, Lincoln, NE, USA) equilibrated with $0.1 \mathrm{M}$ potassium phosphate buffer, $\mathrm{pH}$ 7.0, containing $2 \mathrm{mM}$ EDTA. cAMP binding protein was eluted with $0.3 \mathrm{M}$ potassium phosphate buffer, $\mathrm{pH}$ 7.0, containing $2 \mathrm{mM}$ EDTA. The protein solution represented by the first major peak was collected as suggested (7) and then desalted as described above. The resulting protein solution was concentrated with a stirred ultrafiltration cell (Amicon, Beverly, MA, USA) equipped with a YM-10 Diaflo ${ }^{\circledR}$ ultrafiltration membrane (Amicon) to $125 \mathrm{~mL}$ and centrifuged as described previously to remove undissolved proteins. The supernatant (approximately $120 \mathrm{~mL}$ ) contained cAMP binding protein and was aliquoted and stored at $-20^{\circ} \mathrm{C}$. Using a stir bar situated close to the top of the membrane surface to decrease the rate and extent of concentration polarization and/or cake buildup during the filtration process has the advantages of shorter processing time and longer membrane usage. The alternative to this step is using centrifuge tube devices such as Centricon Plus- $80^{\circledR}$ Centrifugal Filter Units (Millipore, Bedford, MA, USA) that can hold up to $80 \mathrm{~mL}$ initial sample.

\section{Adenylate Cyclase Stimulation Assay and cAMP Binding Protein Assay}

Osteoblastic cells were plated in triplicate into 24-well plates and cultured to confluence. Three extra wells for each group were used for DNA measurement to standardize cAMP levels. The para- thyroid hormone $(\mathrm{PTH})$ receptor-mediated adenylate cyclase response was determined by stimulating cells with hPTH (1-34) (Bachem, Torrance, CA, USA) or vehicle control $(0.1 \%$ BSA with $4 \mathrm{mM}$ $\mathrm{HCl}$ ) in calcium- and magnesium-free Hanks' Balanced Salt Solution (Invitrogen, Carlsbad, CA, USA) containing $0.1 \% \mathrm{BSA}$ and $1 \mathrm{mM}$ isobutylmethylxanthine at $37^{\circ} \mathrm{C}$ for $10 \mathrm{~min}$. After careful aspiration of the medium, cAMP in cells was extracted by adding $250 \mu \mathrm{L} /$ well ice-cold $5 \%$ perchloric acid and incubating for at least $1 \mathrm{~h}$ at $-20^{\circ} \mathrm{C}$. After thaw ing, the cAMP extracts were transferred to borosilicate glass tubes, and the $\mathrm{pH}$ was adjusted to 7.5 with $65 \mu \mathrm{L} 4 \mathrm{M}$ $\mathrm{KOH} /$ well. After centrifugation of the neutralized extract at $950 \times g$ for $10 \mathrm{~min}$ at $4{ }^{\circ} \mathrm{C}$, cAMP levels in the supernatant were determined using the cAMP binding protein assay.

The cAMP binding protein assay was performed by incubating $\left[{ }^{3} \mathrm{H}\right]-$ cAMP (ICN, Irvine, CA, USA) with standards or unknowns and cAMP binding protein sufficient to bind $30 \%$ of radioactivity for $90 \mathrm{~min}$ on ice. The com ponents of the binding protein reaction included $100 \mu \mathrm{L}$ cAMP standards or neutralized cAMP extract of samples, $25 \mu \mathrm{L}\left[{ }^{3} \mathrm{H}\right] \mathrm{cAMP}$, and $125 \mu \mathrm{L}$ diluted cAMP binding protein. cAMP standards with known concentrations $(0.1$, $0.25,0.5,1,2,5,10,20$, and 40 pmol cAMP in $100 \mu \mathrm{L})$ were derived through serial dilution of the stock CAMP $\left(10^{-5}\right.$ $\mathrm{M})$ with cAMP binding buffer $(50 \mathrm{mM}$
Tris- $\mathrm{HCl}, 5 \mathrm{mM}$ EDTA, $0.2 \% \mathrm{BSA}$ ) to generate a standard curve. The cAMP extracts of samples were diluted to the desired concentration (usually 1:10 dilution) with cAMP binding buffer in order to be quantified within the standard curve. Before use, the $\left[{ }^{3} \mathrm{H}\right] \mathrm{cAMP}$ was diluted to $10000-15000 \mathrm{cpm} / 25 \mu \mathrm{L}$ with cAMP binding buffer. The cAMP binding protein was diluted with the cAMP binding buffer to a concentration capable of binding approximately $30 \%$ of the $\left[{ }^{3} \mathrm{H}\right] \mathrm{cAMP}$ added during the reaction (we used a $35 \times$ dilution determined by cAMP binding capacity experiment). The binding protein reaction was conducted on ice for $90 \mathrm{~min}$.

To remove the unbound $\left[{ }^{3} \mathrm{H}\right] \mathrm{cAMP}$, dextran-coated charcoal $(5 \mathrm{mg} / \mathrm{mL}$ charcoal and $0.5 \mathrm{mg} / \mathrm{mL}$ dextran in cAMP binding buffer) was added to the reactants after the binding protein reaction. Following $20 \mathrm{~min}$ incubation on ice, the tubes were centrifuged at $1000 \times$ $g$ at $4{ }^{\circ} \mathrm{C}$ for $20 \mathrm{~min}$ to pellet the dextrancoated charcoal, which bound the free $\left[{ }^{3} \mathrm{H}\right] \mathrm{cAMP}$ present in the reaction mixture. The supernatant of each tube was decanted carefully to a scintillation tube. The radioactivity of the supernatants was determined with a liquid scintillation counter (Wallac ${ }^{\circledR} 1410$; Wallac, Gaithersburg, MD, USA), and cAMP levels were calculated by the log-logit method using the GraphPad Prism ${ }^{\circledR}$ program (GraphPad Software, San Diego, CA, USA) with a standard curve. To standardize the cAMP levels,

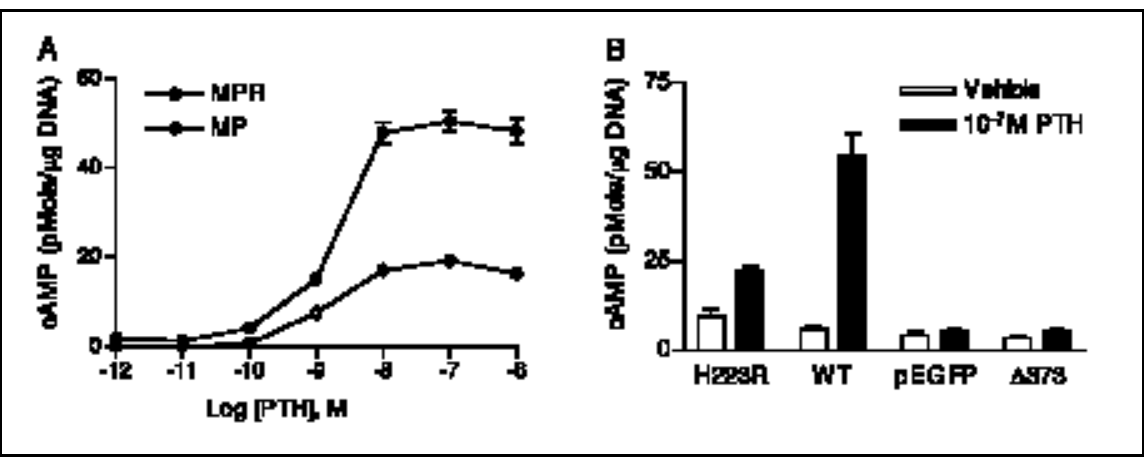

Figure 3. Applications of cAMP binding protein assays. (A) PTH (1-34) dose response curve to evaluate PTH-stimulated cAMP levels. MC3T3-E1 pre-osteoblastic cells stably transfected with plasmid (MP) or plasmid encoding PTH-1 receptors (MPR) were used. cAMP levels versus logarithmic value of PTH stimulation (in M) were plotted. There was a dose-dependent increase in cAMP levels after PTH $\left(10^{-12}-10^{-6} \mathrm{M}\right)$ stimulation. (B) Optimal PTH (1-34) concentration used to determine differences in cAMP responses among multiple cell types. C3H10T1/2 cells transiently transfected with plasmid (pEGFP) or plasmid encoding wild-type PTH-1 receptor (WT), constitutively active PTH-1 mutant receptor $(\mathrm{H} 223 \mathrm{R})$, or inactivated PTH-1 mutant receptor $(\Delta 373)$ were used in a cAMP binding protein assay. Results are standardized to DNA and expressed as $\overline{\mathrm{x}} \pm$ SEM . 


\section{Short Technical Reports}

parallel triplicate wells were analyzed for DNA content by fluorometric analysis as described previously (12).

\section{RESULTS AND DISCUSSION}

\section{cAMP Binding Protein Purification}

The cAMP binding protein was purified from $1 \mathrm{~kg}$ fresh bovine skeletal muscle. After extracting the muscle with distilled water and acid precipitation to remove the contaminating proteins, the cAMP binding protein was isolated through a DEAE-cellulose column (Figure 1). The cAMP binding protein from muscle has been purified with extensive procedures to characterize it as a cAMP-dependent protein kinase (17). However, the cAMP binding protein isolated from the first major peak after addition of $0.3 \mathrm{M}$ potassium phosphate buffer ( $\mathrm{pH}$ 7.0) containing 2
mM EDTA has been shown to be satisfactory for routine use in cAMP binding protein assays (7). Therefore, the protein represented by the first peak was collected. The protein solution was desalted, concentrated, and centrifuged to remove undissolved proteins. The final volume of purified cAMP binding protein was approximately $120 \mathrm{~mL}$.

\section{cAMP Binding Capacity Determination}

The cAMP binding capacity of the purified cAMP binding protein was evaluated. Using the conditions in the cAMP binding protein assay, $125 \mu \mathrm{L}$ different dilutions of cAMP binding protein were incubated with $25 \mu \mathrm{L}$ [ $\left.{ }^{3} \mathrm{H}\right] \mathrm{cAMP}(10000-15000 \mathrm{cpm})$, and the radioactivity was counted after removal of the unbound $\left[{ }^{3} \mathrm{H}\right] \mathrm{cAMP}$ by dextran-coated charcoal. The $35 \times$ dilution of cAMP binding protein was capa- ble of binding about $30 \%$ of the $\left[{ }^{3} \mathrm{H}\right]$ cAMP added (radioactivity counts of bound $\left[{ }^{3} \mathrm{H}\right] \mathrm{cAMP}$ at $35 \times$ dilution equaled about $30 \%$ of the counts of $[3 \mathrm{H}]$ cAMP added). Hence, $35 \times$ dilution of cAMP binding protein was chosen for cAMP binding protein assays. At this dilution, the $120 \mathrm{~mL}$ cAMP binding protein isolated from $1 \mathrm{~kg}$ bovine skeletal muscle would be sufficient for 33600 assay tubes which is equivalent to 170 commercial RIA or EIA kits (typically 200 tubes/kit). The purification procedures of cAMP binding protein cost less than $\$ 500$ dollars for consumable materials (about $\$ 0.015 /$ assay tube). When compared to the unit price of commercial RIA or EIA kits (about \$1.40/assay tube, calculated from $2 \times 96$ wells or 200 tubes/kit for \$250-\$300), the use of laboratory-purified binding protein in a cAMP binding protein assay significantly reduces the cost for cAMP quantification. In addition, the cAMP binding pro- 


\section{Short Technical Reports}

tein remains stable for several years if stored at $-20^{\circ} \mathrm{C}$ without repeated freezing and thawing. This is a major advantage over the short shelf life of commercial kits using iodinated cAMP. The purification procedures of cAMP binding protein described only took about two days and cost approximately $1 \%$ of the price of using commercial kits. Thus, the time spent in purification is quite worthwhile for years of cAMP binding protein supply.

\section{Standard Curve of cAMP Binding Protein Assay}

The standard curve of the cAMP binding protein assay was generated using the isolated cAMP binding protein (Figure 2). The standard curve is linear on counts versus logarithmic value of cAMP standards with $0.1-40$ pmol cAMP in $100 \mu \mathrm{L}$. Thus, the standard curve can be used to quantify cAMP levels within a very wide range.

\section{Applications of cAMP Binding Assays}

cAMP binding protein assays have been used successfully in our laboratory to study PTH receptor-mediated adenylate cyclase activity in cell culture systems. Two examples are shown here. First, using a dose response of PTH (1-34), the sigmoid curve reflecting the biologic activity of the receptor relative to the $\mathrm{Kd}$, can be determined (Figure 3A). MC3T3-E1 cells overexpressing $\mathrm{PTH}-1$ receptors (MPRs) demonstrated more pronounced cAMP stimulation because of the presence of transfected PTH-1 receptors. In addition, using an optimal concentration of PTH (1-34), the stimulated cAMP levels of multiple cell types can be compared (Figure 3B). The H223R group demonstrated the highest basal cAMP level due to the constitutive activity of the PTH-1 receptor. The increased $\mathrm{PTH}-1$ receptors in WT resulted in higher PTH-stimulated cAMP levels in contrast to minimal responses in the presence of inactivated mutant PTH-1 receptors for $\Delta 373$ transfectants or empty vector controls for $\mathrm{pEGFP}$. The sensitivity of the cAMP binding protein assay described is high, for studies of cAMP-dependent signaling path- ways. In our experience, the extracted cAMP samples from cells containing approximately $1 \times 10^{5} \mathrm{PTH}$ receptors/ cell need to be diluted 10 -fold to fall within the standard curve $(11,13)$.

In summary, using updated materials and equipment, we describe a sim ple, economical, and highly efficient method for cAMP binding protein purification. In addition, we described the cAMP binding protein assay techniques that have been successfully adapted in our laboratory to study the cAMP-dependent signaling pathway.

\section{REFERENCES}

1.Billiard, J., S.S. Grewal, L. Lukaesko, P.J. Stork, and P. Rotwein. 2001. Hormonal control of insulin-like growth factor I gene transcription in human osteoblasts: dual actions of cAMP-dependent protein kinase on CCAAT/ enhancer-binding protein delta. J. Biol. Chem. 276:31238-31246.

2.Boguslawski, G., L.V. Hale, X.P. Yu, R.R. Miles, J.E. Onyia, R.F. Santerre, and S. Chandrasekhar. 2000. Activation of osteocalcin transcription involves interaction of protein kinase A- and protein kinase C-dependent pathways. J. Biol. Chem. 275:999-1006.

3.Boucher, M.J., C. Duchesne, J. Laine, J. Morisset, and N. Rivard. 2001. cAMP protection of pancreatic cancer cells against apoptosis induced by ERK inhibition. Biochem. Biophys. Res. Commun. 285:207-216.

4.Daniels, C.K., L. Zhang, B. Musser, and R.E. Vestal. 1994. A solid-phase radioimmunoassay for cyclic AMP. J. Pharmacol. Toxicol. Methods 31:41-46.

5.Donahue, H.J., Z. Zhou, Z. Li, and L.K. McCauley. 1997. Age-related decreases in stimulatory $\mathrm{G}$ protein-coupled adenylate cyclase activity in osteoblastic cells. Am. J. Physiol. 273:E776-E781

6.Fischer, E.H. and E.G. Krebs. 1958. The isolation and crystallization of rabbit skeletal muscle phosphorylase b. J. Biol. Chem. 231:65-71.

7.Gilman, A.G. 1970. A protein binding assay for adenosine $3^{\prime}: 5^{\prime}$-cyclic monophosphate. Proc. Natl. Acad. Sci. USA 67:305-312.

8.Horton, J.K., R.C. Martin, S. Kalinka, A. Cushing, J.P. Kitcher, M.J. O'Sullivan, and P.M. Baxendale. 1992. Enzyme immunoassays for the estimation of adenosine $3^{\prime}, 5^{\prime}$ cyclic monophosphate and guanosine $3^{\prime}, 5^{\prime}$ cyclic monophosphate in biological fluids. J. Im munol. Methods 155:31-40.

9.Lee, C.H., K. Sidik, and K.V. Chin. 2001. Role of cAMP-dependent protein kinase in the regulation of DNA repair. Cancer Lett. 169:5158.

10.Locatelli, F., C. LaFourcade, H. Maldonado, and A. Romano. 2001. Characterization of cAMP-dependent protein kinase isoforms in the brain of the crab Chasmagnathus. J. Comp. Physiol. B 171:33-40.

11.McCauley, L.K., C.A. Beecher, M.E. Melton, J.R. Werkmeister, H. Jüppner, A.B. Abou-
Samra, G.V. Segre, and T.J. Rosol. 1994. Transforming growth factor- $\beta 1$ regulates steady-state PTH/PTHrP receptor mRNA levels and PTHrP binding in ROS 17/2.8 osteosarcoma cells. Mol. Cell. Endocrinol. 101:331336.

12.McCauley, L.K., A.J. Koh, C.A. Beecher, Y. Cui, J.D. Decker, and R.T. Franceschi. 1995 Effects of differentiation and transforming growth factor $\beta 1$ on $\mathrm{PTH} / \mathrm{PTHrP}$ receptor mRNA levels in MC3T3-E1 cells. J. Bone Miner. Res. 10:1243-1255.

13.McCauley, L.K., A.J. Koh, C.A. Beecher, Y. Cui, T.J. Rosol, and R.T. Franceschi. 1996. $\mathrm{PTH} / \mathrm{PTHrP}$ receptor is temporally regulated during osteoblast differentiation and is associated with collagen synthesis. J. Cell. Biochem. 61:638-647.

14.Miyamoto, E., J.F. Kuo, and P. Greengard. 1969. Cyclic nucleotide-dependent protein kinases. III. Purification and properties of adenosine $3^{\prime}, 5^{\prime}$-monophosphate-dependent protein kinases from bovine brain. J. Biol. Chem. 244:6395-6402.

15.Rall, T. and E. Sutherland. 1958. Formation of a cyclic adenine ribonucleotide by tissue particles. J. Biol. Chem. 232:1065-1076.

16.Renger, J.J., A. Ueda, H.L. Atwood, C.K. Govind, and C.F. Wu. 2000. Role of cAMP cascade in synaptic stability and plasticity: ultrastructural and physiological analyses of individual synaptic boutons in Drosophila memory mutants. J. Neurosci. 20:3980-3992.

17.Walsh, D.A., J.P. Perkins, and E.G. Krebs. 1968. An adenosine $3^{\prime}, 5^{\prime}$-monophosphate-dependant protein kinase from rabbit skeletal muscle. J. Biol. Chem. 243:3763-3765.

We gratefully acknowledge Dr. Qiming Jin and Ms. Kerry Jacobson for advice in cAMP binding protein purification. In addition, we would like to thank Dr. Martha Somerman for kind support with equipment for chromatography. Finally, we also thank Drs. Ernestina Schipani and Caroline Silve for providing us with H223R and $\Delta 373-383$ mutant PTH-1 receptor constructs. This work was supported by National Institutes of Health grant nos. DK53904 to L.K.M and DE00452-01 to N.J.D., as well as the Center for Biorestoration of Oral Health. Address correspondence to Dr. Laurie K. McCauley, Department of Periodontics/Prevention/ Geriatrics, University of Michigan, $1011 \mathrm{~N}$ University Ave., Ann Arbor, MI 48109-1078, USA.e-mail: mccauley@umich.edu

Received 28 November 2001; accepted 1 April 2002.

Hen-Li Chen, Laurie K. McCauley, and Nisha J. D'Silva

University of Michigan

Ann Arbor, MI, USA 